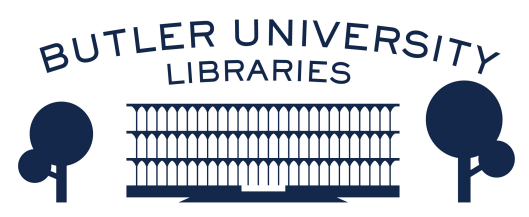

Journal of Hindu-Christian Studies

Volume 16

Article 16

January 2003

\title{
Book Review: "Hindu-Christian Dialogue. Theological Soundings and Perspectives"
}

Anand Amaladass

Follow this and additional works at: https://digitalcommons.butler.edu/jhcs

Part of the Religion Commons

\section{Recommended Citation}

Amaladass, Anand (2003) "Book Review: "Hindu-Christian Dialogue. Theological Soundings and Perspectives"," Journal of Hindu-Christian Studies: Vol. 16, Article 16.

Available at: https://doi.org/10.7825/2164-6279.1305

The Journal of Hindu-Christian Studies is a publication of the Society for Hindu-Christian Studies. The digital version is made available by Digital Commons @ Butler University. For questions about the Journal or the Society, please contact cbauman@butler.edu. For more information about Digital Commons @ Butler University, please contact digitalscholarship@butler.edu. 
Abhishiktananda and Bede Griffiths) - but of the advaitan meaning of Incarnation.
Bruno Barnhart

New Camaldoli Hermitage, Big Sur

\section{Hindu-Christian Dialogue. Theological Soundings and Perspectives (Currents of Encounter, Vol.18). Mariasusai Dhavamony. Amsterdam-New York: Editions Rodopi B.V., 2002, 222 pp.}

THE title of the book explains specifically what it is all about. It has 12 chapters, besides the introduction and conclusion, dealing with several themes from the HinduChristian perspectives. Major themes are the idea of God - which includes the creative word: Siva-Sakti and Logos, Trinity-, revelation, salvation, monasticism, prayer and meditation, which offer scope for comparison, citing parallel texts from both the traditions. They are treated as Christian approaches to Hinduism evaluating from the Christian standpoint.

The author of the book has been teaching Hinduism for the last 40 years at the Pontifical Gregorian University in Rome and the readers will be familiar with these themes from his major publications like Love of God according to Saiva Siddhanta (1971), Classical Hinduism (1982), Hindu Spirituality (1999). But now what is new in this work is the perspective, namely, looking at the themes from the point of view of inter-religious dialogue. In fact he devotes his whole introduction to explain what is meant by dialogue and as a result the tone of the book and the emphasis change. The meaning of dialogue is presented by referring to the classical authors on the topic like Reuel L. Howe, Martin Buber and A.D. Lindsay.

Prof. Dhavamony has been a member of the pontifical counsel for inter-religious dialogue for two decades and one can notice this from his language; it is the theological perspective that initiates dialogue. In fact he begins his book by saying that " the gift of God in Christ, the Gospel message, is meant for all people and the Church is sent to the entire world to communicate this message."(p.7). There has been a series of documents brought out among the Christian communities to clarify to themselves the need and the goal of dialogue. For a Christian dialogue is the way of discovering God's mystery at work in other faith traditions and cultures and the spiritual encounter with believers of other religions is meant to help them discover deeper dimensions of Christian faith and wider horizons of God's salvific presence in the world. This is an important clarification to be kept in mind in order to avoid any misunderstanding about the Christian approach.

Hence this book makes it clear that inter-religious dialogue is not merely an intellectual joy of discovery by scholars nor a detached venture of the comparativists from different disciplines, but a faith commitment of believers who search for the mystery of truth revealed in different traditions. Obviously this would call for further reflection on integrating one's tradition with that of others. It is an ongoing process before a common horizon of understanding emerges. These days several publications are seen with the desire of crossing the borders, with the cross-cultural or intercultural outlook both in philosophy and theology and they are only indications of a search, though it looks at the moment that the search is asymmetrical, since not all traditions appear to be equal partners in dialogue nor fully participating in this process for obvious reasons. 
The author of this book is aware of the Christian anomalies too prevalent today, and so he draws attention to the extreme positions in the approach towards the Hindus, either being too negative without respect for them or compromising one's own faith "by just doing social work without even mentioning the name of Christ while dealing with the Hindus."(p.189). There should be concern both for the Gospel and for the Hindu brethren. An exaggerated love of one's religion without the love of the neighbour has cost humanity bloody wars and quarrels.(p. 201)

This book is a helpful source of information regarding the areas of common interests, identifying the points of convergence in Hindu Christian dialogue. Obviously it is a Christian approach to the Hindu religion inspired by its theological presuppositions. But it has to be open enough to be critiqued by the Hindu community as well, since the religious texts of a particular tradition cannot be interpreted from outside. Hence it calls for further reflection from the dialogue partners of both the traditions - Hindu and Christian.

Anand Amaladass Chennai

\section{Christianity at the Religious Roundtable. Evangelicalism in Conversation with Hinduism, Buddhism, and Islam. Timothy C. Tennent. Grand Rapids, MI: Baker Academic, 2002, 270 pp.}

THE AUTHOR is an evangelical Christian missiologist who teaches at Gordon-Conwell Theological Seminary in the U.S. and at the Luther New Theological College in India. The roundtable "conversation" he advocates ultimately serves an apologetic purpose: to show the superiority of traditional Christian soteriology and biblical creation ontology over the teachings of the three other faith traditions named in the book's subtitle. The volume is simultaneously an attack on the contemporary inclusivism of Roman Catholicism and the pluralist positions of important Western Christian writers such as John Hick, Paul Knitter and others. Tennent draws not only on Bible and Christian theology and on authoritative works of Hinduism, Buddhism, and Islam, but also on the "many conversations I have had with Muslims, Hindus, and Buddhists from all over the world". (p. 11) He thereby attempts to overcome the generally "embarrassingly superficial" literature on different religions hitherto presented by other evangelical Christian writers, and he goes on to challenge them to actively engage in interreligious dialogue. In this the author's aim is laudable.

After an opening chapter assessing the various contemporary approaches taken by Christians to interreligious dialogue, the next six chapters, the heart of the book, provide the author with the opportunity to engage in imaginary and sympathetic dialogue with two Hindus (representing Advaita and Visistadvaita Vedanta), two Buddhists (advocating Madhyamika and Yogacara), and three Muslims (espousing Sunnism, Shi'ism, and Sufism) on such key issues as God, creation, ethics, incarnation and Trinity. We thus note from the outset the omission of a great many possible issues and schools of thought; but this restriction enables the topics chosen to be treated with adequate depth. Each debate ends with an authoritative evangelical Christian response as a kind of siddhanta or final correct view. The last three chapters of the book examine in succession Justin Martyr's use of "logos spermatikos," Brahmabandhav Upadhyay's rearticulation of the Trinity in terms of 